Swarts, G.P Re/coding Global Citizenship: How Information and Communication Technologies have Altered Humanity and Created New Questions for Global Citizenship Education

\title{
Re/coding Global Citizenship: How Information and Communication Technologies have Altered Humanity and Created New Questions for Global Citizenship Education
}

\author{
Gabriel P. Swarts, PhD.* \\ St. Bonaventure University \\ *Corresponding Author: gswarts@sbu.edu \\ Received : 2019-08-30 \\ Accepted : 2019-11-02
}

\begin{abstract}
How to cite this paper: Swarts, G.P (2020). Re/coding global citizenship: How information and communication technologies have altered humanity and created new questions for global citizenship education. Research in Social Sciences and Technology, 5(1), 7085.
\end{abstract}

\section{Abstract}

In the broadest sense, the concept of global citizenship education (GCE) includes many facets of a rapidly changing world and concepts in education. The information and communication technology (ICT) advances of the last few decades have created opportunities for educational connection and interaction through digital spaces at all levels, local and global. In linking technology with global citizenship, neither GCE nor ICTs can be assumed to be mutually progressive and/or mutually beneficial. In recent years, governments have moved to centralize ICT technologies exacting more control over their use for surveillance, including the weaponization of ICTs for strategic gains. This complicates the work of GCE scholars and practitioners in unforeseen ways as centralized control limits decentralized interactions. ICT concepts and philosophical stances are explored and defined to address how GCE scholars and practitioners can reimagine and reframe the tenets of the field within this informational world. Key topics discussed include complications of GCE in the infosphere, digital citizenship \& GCE, and teaching GCE in the age of "inforgs" \& digital identities.

Keywords: Global citizenship education, Government control, Information and communication technologies

\section{Guiding Question}

How does the changing nature of human beings more increasingly moving from a physical to digital existence open new spaces for defining and conceptualizing global citizenship education?

\section{Introduction}

When looking at the ways in which human beings access information, the technological expansion of what we know and is known has occurred at an explosive pace. The breadth and depth of information/data being produced and consumed through information and communication technologies (ICTS) has never before happened in human history. Human data 
Swarts, G.P Re/coding Global Citizenship: How Information and Communication Technologies have Altered Humanity and Created New Questions for Global Citizenship Education

output nearly doubles every year; for example, in 2019 alone, humans produced as much data as they did in all of human history up through 2018 (Helbing et al., 2017).

At the same time, cooperation among social and political groups is becoming more critical each year. Worldwide, there is political turmoil, a mounting refugee crisis, and imminent ecological catastrophe, all of which will require the cooperation of humans across borders, national identities, and culture necessitating the deepest levels of communication, respect, global partnership, and commitment. Technology corporations and government entities have engaged in unprecedented control of ICTs and the oceans of data they produce while democratic protestors and individual actors use ICTs to challenge political structures and practices. Through exploding technologies and data, this moment in history is reshuffling longheld social and political relationships, including concepts of community, belonging, and citizenship. In the field of global citizenship education (GCE), this radical shift has presented new opportunities and challenges to a field that is of paramount importance in educating students for a world that demands global human coordination, interaction, and problemsolving.

Recent trends and technological breakthroughs have made it necessary for educational fields and sub-fields to adapt institutional values, theory, and practice immediately. The technological infrastructure needed to place ICTs in every corner of the globe has arrived and thrived. As of 2019, an average of 57 percent of people in the world are connected to the internet, up from 35 percent in 2013 (Statista, 2019). At the same time, challenges to political, environmental, and social well-being have swiftly attained critical levels: There are a record number of displaced persons in the world, climate change scientists are publishing ever more concerning studies and issuing dire warnings for human survival, and political disruption and isolation has made international cooperation more difficult to nurture and achieve. An adapted GCE theory and practice is necessary for a long-term, foundational restructuring of individual values, literacies, and perspectives.

\section{Global citizenship education in the $21^{\text {st }}$ century}

Though a contested field with various meanings and value statements, consistent GCE definitions have been adopted by official transnational organizations such as the United Nations Education, Science, and Cultural Organization (UNESCO), Oxfam, and the Organization of Economic Cooperation and Development (OECD). UNESCO describes GCE in the 2030 Education Agenda Framework for Action as "aim(ing) to empower learners of all ages to assume active roles, both locally and globally, in building more peaceful, tolerant, inclusive and secure societies" (UNESCO, 2019). As a framework for learning and reaching into the wider community, GCE requires commitment to engage with the world and use skills within the curriculum to champion equality, sustainability, and fairness (Oxfam Education, 2019).

Relating GCE to technological advancement is sporadic. Although UNESCO and Oxfam do not include ICTs or digital frameworks in their definitions as of 2019, the OECD directly links 
Swarts, G.P Re/coding Global Citizenship: How Information and Communication Technologies have Altered Humanity and Created New Questions for Global Citizenship Education

technological changes to global citizenship values and practices in their publication on assessing global competencies, saying that:

Online networks, social media and interactive technologies are giving rise to new types of learning, where young people exercise greater control over what and how they learn. At the same time, young people's digital lives can cause them to disconnect from themselves and the world, and ignore the impact that their actions may have on others... Likewise, access to an unlimited amount of information is often paired with insufficient media literacy, meaning that young people are easily fooled by partisan, biased or fake news. In this context, cultivating students' global competence can help them to capitalise on digital spaces, better understand the world they live in and responsibly express their voice online. (OECD, 2018, p. 5)

This summary identifies a key focus of this paper: the balance between privacy and presence, control and freedom, within increasingly polarized political environments in many nation-states. At the same time, the threats to human existence discussed in the introduction loom large and require unprecedented human cooperation. Therefore, a discussion of how ICTs are changing the landscape, and how GCE must open new spaces for conversations and the future of the field, is the key focus of this article. Marrying the opportunities and challenges that face global citizenship education in the $21^{\text {st }}$ century truly requires a reassessment of how GCE scholars, organizations, and practitioners think about the components of the field within technological change and the realities of pervasive ICTs.

\section{A large-scale technological "disruption"}

Increasingly, humans are becoming more digitized and are more and more constructed of the data they produce. In industries where this has occurred recently, the idea that technology will "disrupt" traditional norms and practices has taken hold in popular culture. Music, movies, and automated industries have all experienced disrupting practices in recent decades.

Understanding human beings as both physical beings and digital constructions, to form a disrupted entity, is a profoundly new idea that has important ramifications for education (Floridi, 2010). The "re/coding" of the key elements of education in this disrupted age, specifically GCE, can be balanced and partnered with the incorporation of ICT theory and research to allow for spaces that enable a dual understanding of the elements and dynamics impacting the digital data and information. Expanding and exploring new avenues for GCE theory and practice must occur in digital and physical spaces and requires a reexamination of what constitutes a human, a citizen, and what human society could be in the information age. To set the foundation of further discussion, this article explores three influential shifts in how humans use and exist with ICTs. Each one of these trends is explored briefly, followed by a discussion linking these trends to key tenets of GCE, and finally, educational spaces are explored in which ICT trends and GCE tenets can be integrated. As institutions, theories, and practices must adapt in many disrupted fields to the pervasive presence of ICTs and data, GCE 
Swarts, G.P Re/coding Global Citizenship: How Information and Communication Technologies have Altered Humanity and Created New Questions for Global Citizenship Education

can build upon existing frameworks and epistemologies in global education and technology to reflect upon and address key issues and trends in the field.

\section{Three technology-driven challenges for global citizenship education}

This article addresses three key challenges that GCE teachers and scholars face to "re/code" the field in the information age. Building upon GCE literature that has explored the often competing/complementing discourses of the field for decades, there are three areas related to GCE being "disrupted" as human beings further shift into the digital realm: 1) how humans engage with global issues and concerns, 2) the role of governments and citizenship status in a "disrupted" age, and 3) the role of technology corporations in the delivery and control of globalized media. The changing digital behaviors and norms of human beings, the roles of government, and the influence of media through ICTs has presented unique and complex problems that GCE practitioners and theorists must begin to address in their work.

What tools can aid in rethinking GCE? There are three conceptual frameworks that can assist in a re-imagining of GCE in the information age and can facilitate new spaces for conversations about how GCE can contribute to the needs of human society: 1) the changing nature of humanity as explained through the concept of inforgs, or informational organisms, 2) increased (though not total) government control and presence of ICTs in the political sphere, and 3) corporate control and the "centralization" of ICTs facilitating the concretization of the hyperreal. Each of these three frameworks is summarized and then linked to GCE to explore possibilities and spaces that GCE scholars and advocates can use to begin to reassess the role of GCE in a technologically disrupted world.

Becoming Inforgs. Forget the cyborg of science fiction movies - instead of part human and part machine construction, Google searches, Facebook posts, and our medical records have been attached to our human existence and represent our informational selves. To understand this perspective, think of all the texts, videos, online purchases, web searches, comments, pictures, and digital records containing your name and information. With millions of data points for each person in a majority of the world, it is not hard to see how the "digital exhaust" we produce has outpaced our physical presence (Neff, 2015). For GCE, this requires a new perspective on how to define human beings in many arenas, including debates of citizenship and legal status. These ICT advances of the last few decades have created opportunities for human connection and interaction through digital spaces at all levels, local and global. This infrastructure and interconnectedness has been built upon unprecedented levels of data creation, control, and access by human, technology, and government actors.

According to Luciano Floridi (2010, 2011a, 2014), digital spaces have become so influential in how we live that an entirely new version of humanity must be conceptualized; informational representations of self and world now constitute so much territory in our daily existence that humans could now be defined and constructed as informational entities through the data they produce and consume. This digital world, Floridi's infosphere, is constructed of the digitization 
Swarts, G.P Re/coding Global Citizenship: How Information and Communication Technologies have Altered Humanity and Created New Questions for Global Citizenship Education

of human beings as informational organisms, or inforgs. This extends the conceptualization of digital representations of human beings from a mere part of human existence to the way that humans are now defined. Due to data production and dissemination, humans now exist more in the digital world than in the physical, which Floridi calls the onlife. Simply put, who we "are" can be most accurately be defined through the data we produce and consume.

ICTs, artificial intelligence (AI), and virtual reality/augmented reality (VR/AR) are becoming more and more prevalent in our daily lives. Logging on to ICTs for screen time now constitutes a majority of our waking hours (Combi, 2015; Howard, 2016). As our worlds increasingly become an onlife, our personal information available in macro data sets (i.e., Facebook's data stores), we are beholden to understand and live more in the world of information and data. Understanding this shift in how we are "seen" by other human beings and ICTs makes for new work to be done in addressing human problems like climate change or the refugee crises.

2) Government control of information, citizens. The political layers that have impacted GCE theory and practice have been heavily investing in social, political, and economic presence in the digital realm for decades. Conceptions of citizenship and governmental relations are undergoing titanic changes through further centralized government control and power of data and ICTs (Christensen, 2019; Moss, 2018; Robbins \& Henschke, 2017). Although this expansion into information and data collection is consistently being challenged in the courts (i.e., the FISA courts in the U.S.), governments all over the world are rapidly increasing information collection and storage capabilities (Kayali, 2018; Scott \& Gold, 2018). As part of a wider movement in the last two decades, large-scale data production and control is now part of a broader civic movement of state (and corporate) actors dictating information access, transparency, and utilization (Amnesty International, 2018; Malcomson, 2016; Robbins \& Henschke, 2017).

As inforgs, existence constructed of information which can be traced, replicated, viewed, and transported at the speed of light is more vulnerable to corporate and government surveillance and intervention (Draper, 2018). While visions of government as "Big Brother" leap out of that description, the government/onlife relationship of today is different in many key aspects:

First, this system has largely been created through private construction and voluntary participation of individuals (i.e., when we sign up for an Instagram account), requiring governments to catch up with their own systems or to latch on to the private sector. For example, Chinese officials solicited bids from seven private tech companies to build the Social Credit System architecture and are already pushing Al agents in classrooms (Botsman, 2017; Hao, 2019). Second, embracing government use of Big Data and ICTs is uneven. London officials and citizens, as well as those in China, are much more open to video surveillance and assume its existence, while there is a much more divisive discourse occurring in the U.S. regarding privacy rights and information ownership (Leong, 2018; Scott \& Gold, 2018). The same can be said for educational institutions and how they think of and utilize data, as well as how students, teachers, parents, and faculty may utilize, avoid, or understand data usage and possibility. Therefore, humans in different parts of the world participate at different levels in ICTs, and with 
Swarts, G.P Re/coding Global Citizenship: How Information and Communication Technologies have Altered Humanity and Created New Questions for Global Citizenship Education

different levels of autonomy and critical understanding of how their participation changes their status as inforgs. Third, the control of information is uneven and can be countered. Various protest movements and transnational social partnerships have facilitated mass organization and popular political mobilization of specific groups, political and social (i.e., the Arab Spring protests, the Hong Kong protests, and coordinated teachers' union protests in various parts of the U.S.).

In addition to revolutionary changes in how we think of information, data, and ICTs, there is one more evolutionary layer influencing how we view the role of GCE in the information age: The expansion of government in the collection of data and utilization of ICTs has occurred within a profound political shift in which historically established liberal democracies trend toward authoritarian control. China, the U.S., and countries in Europe and South America are seeing tighter restrictions on civil liberties and free press and increased public protests (Chistensen \& Groshek, 2019). In this political and social metamorphosis, ICTs are being controlled, manipulated, and utilized by authoritarian regimes in deeper ways to challenge democratic existence and practice while at the same time providing conduits for antigovernment action and protest. This trend requires urgent attention and acknowledgment in a variety of public forums as political and civic communication methods expand for both the public and authoritarian impulses (AI Now Report, 2017).

The infosphere is an expanding space for conceptualizing and imagining what GCE could be, and these technological processes should be addressed critically. In linking technology with global citizenship, neither GCE theory and practice nor ICT theory can be assumed to be progressive and/or mutually beneficial (Andreotti \& Pashby, 2013). In recent years, governments have moved to centralize ICT technologies, exacting more control over their use for surveillance, including the weaponization of ICTs for strategic gains, and citizens have used ICTs to organize and challenge governments. These emergent conflicts, with multiple political and civic actors utilizing the same technological structures and trends for competing ends, complicates the work of GCE scholars and practitioners in unforeseen ways. Within this context, GCE teachers and scholars must continue to define and construct a space within citizenship education discourse that emphasizes use and practice of ICTs within the changing landscape of data, communication, and privacy (ISTE, 2019). Building open foundational frameworks of GCE-UNESCO, OECD, and Oxfam in this paper-through the conduit of ICTs opens up the possibilities of connection and communication among GCE participants and understanding the role governments play in information and data collection and access; GCE organizations must stake their own territory for digital communications and data. Regardless of student nationality or geographic location, ICTs will impact the way they see the world as global citizens and how they interact with and shape multilayered political and civic institutions.

3) Corporate dominance and the hyperreal. In studying who has the ability to collect and parse through the pedabytes of data humans produce in a given year, Amy Webb explores the nine behemoth corporations that control ICTs throughout the world (Webb, 2019). Covering tech companies in Silicon Valley and China, Webb explores the two largest poles of tech 
Swarts, G.P Re/coding Global Citizenship: How Information and Communication Technologies have Altered Humanity and Created New Questions for Global Citizenship Education

development in the world today and the nine corporations that develop and control ICTs and the data they produce. Webb's thesis maintains that these nine corporations have almost complete control over how our personal data is collected, sorted, and accessed, and the ramifications of that level of power has created entities that rival nation-states in influence and power.

While the internal machinations of governments can be somewhat compartmentalized within borders of nation-states, corporate entities have a global influence and reach at a much faster rate. Long at the center of GCE scholarship, the role of corporations and their interests in education requires critical study and critique to maintain balance and orchestrate challenges when values conflict (Mikander, 2016; Pais \& Costa, 2017; Torres, 2017b). Media corporations, which include social media and tech companies like Facebook, Amazon, Twitter, Google, etc., have more access to "who" we are as inforgs than any other entity in history. This new dynamic introduces further hegemonic characteristics into the consumer/producer relationship that has led to a myriad of legislative acts (Satariano, 2019), political critiques (Romm, 2019), and popular protests (NAACP, 2019).

Corporate-run ICTs act upon the data they accrue, which is then used and interpreted by corporate and government entities. Increasingly, these corporations are becoming further enmeshed in governmental partnerships (i.e., Amazon and the U.S. government or Ring and local police departments) to advance business plans and/or political agendas (Harwell, 2019; Haskins, 2019). This ubiquitous access to data allows for ICTs to have further control of who and what we are, and allows data and the information we see to be open to limitations, the "nudging" of our decision-making, and outright deception (i.e., Russian election interference). The manipulatives of media and data and the inextricable symbiosis of the corporate/government partnership has created an environment in which digitized existence has taken place of original interaction. Jean Baudrillard described this process as the "hyperreal" (Baudrillard, 1994/2004). The reorientation of previously known symbols (such as human conversation or global travel, and most importantly in this paper, citizenship) to the simulated (Snapchat messaging, Instagram photos, video) has allowed for a departure of a grounding to the "knowable" and allows for envisioning a society or an educational approach that is uniquely fantastical and imaginary. Society is now "free" from the grounded truth (Baudrillard, 2007, p. 25). This "untethering" has ushered in a profound set of problems in which our "selves" are now constituted digitally and are therefore susceptible to information manipulation, as well as the necessity to rethink how information and knowledge is theorized to rethink how we create and experience global citizenship curriculum. As corporate actors continue to control and manipulate our experiences, the access to our data, the ability for hyperreal interpretations of many aspects of our lives, including foundational tenets of GCE such as global presence, global competency, intercultural sensitivity, and perspective consciousness, become tainted or skewed (Hanvey, 1976). This altered state is happening at exactly the moment that these tenets are needed most to organize around the immediacy of global challenges. This requires faithful, heartfelt dialogue and deliberation, not hyperreality. 
Swarts, G.P Re/coding Global Citizenship: How Information and Communication Technologies have Altered Humanity and Created New Questions for Global Citizenship Education

Baudrillard's work is valuable in reassessing our relationships to ICTs/Als/educational corporations (like Pearson) within a GCE setting. This reassessment is important in two distinct ways: as a critical reassessment of the challenges posed to ICTs in GCE, and as a reassessment of the positive and more fruitful impacts that ICTs have on GCE. Starting with the Arab Spring protests and now the Hong Kong protests against the influence of mainland China, the key tenets of GCE that support liberal democratic freedoms and values across national borders can be amplified through ICTs. The same technologies that allow China to track Hong Kong protestors and use facial recognition to target Uyghur Muslims also allow counter-state protests and the proliferation of democratic practices and values. ICTs have been shown to facilitate transnational social movements and allow for spaces to engage participants in democratic processes across borders (Cammaerts, 2017).

At once controlling and controlled, humans will be further defined as informational organisms the further we journey into the ICT revolution, which raises important questions: Will the "objectivity" of humanity and the defining characteristics of global citizenship education, and education at large, continue and thrive through ICT conduits? Or could these values and practices in GCE be broken down into Baudrillard's simulacra, like a sophisticated Al tutor that mimics teaching pedagogy, transitioning into fully virtual spaces and data points that are unable to be pinned down as a physical experience or journey (Edwards \& Usher, 2002, p. 11)?

\section{New spaces for Global Citizenship Education in the infosphere}

As ICTs become even more prevalent and more deeply embedded in educational settings, their influence on curriculum discourses, teaching practices and theory, and student learning experiences will amplify Floridi and Baudrillard's concepts, under the umbrella of corporate and governmental control, and will force schools and the humans within them to adapt. Van Kessel and Kline (2019) believe that schools, as agencies of state (public) and corporate (for profit), are complicit in this "murder" of the real, propping up Baudrillard's hyperreal as a truth of experience and maintaining that "instead of functioning to reveal the world of simulation as a means of defending the real, schools continue to be an accomplice to its murder by simulating at the levels of curriculum, policy, and operations" (p. 18).

The tensions among schools and state demands have always been present. Muddling through the drastic changes in information, data, privacy, and traditional educational aims continues to be a source of much-needed reflection and research (Swarts, 2019). Understanding how technology can decouple students from topics or experiences that have benefitted GCE programming in the past or research into new approaches allows for a more critical look into technology adoption and usage as well as data privacy and information concerns while using and incorporating ICTS.

The idea of an open, freely connected network of ICTs that allow for wide-ranging perspectives, sharing of experiences, and human creativity is still the backbone of the onlife. Although government and corporate actors have subsumed much of the infrastructure of the infosphere 
Swarts, G.P Re/coding Global Citizenship: How Information and Communication Technologies have Altered Humanity and Created New Questions for Global Citizenship Education

(Malcolmson, 2016), there are many openings and possibilities for students and teachers to explore GCE values and curricula. Schools have already started to incorporate ICTs into learning for a variety of reasons, but as adoption of GCE curriculum is uneven, so is the adoption of ICTs and the comprehensive data planning by schools to store and protect the academic, biological, and social data they collect.

How are ICTs already impacting schools? Educational institutions have shown a willingness to invest in ICTs for security and assessment purposes more than specific curriculum aims or within certain school settings; Al and ICT-based technologies are furthering the "surveillance" role of schools and teachers. Eye monitoring software on district devices to track engagement with an assessment or application (e.g., Tobii Pro), facial recognition software to track student locations (SAFR by RealNetworks), and RFID chip-enabled student ID cards to take attendance (Roscorla, 2012) allow schools to monitor and correct behavior in far more invasive ways than ever before. And while each generation of students experiences different mechanisms of control and surveillance in schools, the possibility that this information can be utilized through district applications that rely on student biological, academic, and affective data allows for many more access points for teaching, learning, correction, and coercion.

As schools further adopt ICTs for a variety of reasons, at the core of these technological advances are many questions for GCE scholars about new possibilities. Emerging discussions in this article and beyond focus on this changing view of information and what it is to be human/information/agent in a disrupted field (and world). These questions could include the following work in curriculum studies and educational scholarship at large:

1. Could GCE scholars focus on how identity is blurring between the physical and onlife? If more and more of our "self" is curated and maintained online in relation to other "selves," then so, too, are political and civic expositions and connectivity, especially on a global scale (Hart, Richardson, \& Wilkenfeld, 2012; Hongladoram, 2011; Floridi, 2011b). This focus could allow for continued discussions on how individuals can impact large-scale problems in coordinated efforts through ICTs that influence and impact traditional political structures.

2. As ICTs adapt and can translate language in real time while collecting and learning from large data sets of video and photographs, how do cultural elements of language practice and expression translate? How will ICTs aid in dialogue and understanding as they become more useful and intelligent, building on immense collections of information? Could these tools enable even more cohesive communications and value statements? What about building on existing intercultural theories to advance intercultural communication? Or, will ICTs continue to reinforce human biases in educational, legal, and social settings (Dellinger, 2019)? GCE tenets require communication and understanding of many "others" in order to advance causes important to human society and ecological sustainability. Educating 
Swarts, G.P Re/coding Global Citizenship: How Information and Communication Technologies have Altered Humanity and Created New Questions for Global Citizenship Education

active global citizens with the ability to produce, access, and interpret data within a GCE framework changes what information is valued and how it is communicated.

3. Today (or even further into the future when Al develops feelings and disposition as well as the ability to express them), what are our educational responsibilities to these agents? Do we have a civic and moral duty to educate learning ICTs/Als within the parameters of sound GCE theory and practice to fulfill the highest ideals of the field? How do we attempt this work of including Al into GCE? And how will our own education and curriculum knowledge change as we attempt to educate Al agents and work with them to amplify human intelligence (Baker, 2016)? As the ethics of Al and related fields are continually debated, the concept of value sensitive design (VSD) has been accepted: Things that humans design reflect human values, and designs can include values that reduce harm, maintain the value of the ecosystem, and make decisions to bolster cross-cultural interaction and respect. Therefore, any advanced $\mathrm{Al}$ can include the best of human values, such as the tenets of GCE, and this can be done intentionally. So, how can GCE ideals be purposefully included within machine learning and AI design processes, and through what channels can GCE scholars and practitioners influence engineers?

4. Lastly, what is data, what are the data ethics we should consider, and how should we use data in GCE? What limitations must we place on the creation and utilization of our "digital exhaust" (Neff, 2015)? Some governments have begun the legal and ethical discussions, as have scholars in technologyrelated fields; however, this conversation is severely lacking in education and GCE. Data is viewed as positive and necessary for the function of teaching and schools, but the new types and approaches to data usage and collection necessitate a vigorous debate about how this data will impact our students and teachers, especially in the most vulnerable school districts.

\section{Conclusion}

To look forward, some key ideas from past cosmopolitans can help frame the complications of GCE and ICTs. John Dewey's ideal educational mission was not only a social one but also focused on schools and education addressing societal problems. From his School and Society lectures, Dewey laid out his vision of the relationship between school and greater human society:

We must conceive of [schools] in their social significance, as types of the processes by which society keeps itself going, as agencies for bringing home to the child some of the primal necessities of community life, and as ways in which these needs have been met by the growing insight and ingenuity of man; in short, as instrumentalities through which the school itself shall be made a genuine form of active community life.... (Dewey, 1907, p. 26) 
Swarts, G.P Re/coding Global Citizenship: How Information and Communication Technologies have Altered Humanity and Created New Questions for Global Citizenship Education

In Dewey's words, schools must be instruments of solution. In the present, the challenges of society as well as the information revolution are inherently global and immediate, which necessitates a global concert of actors, governments, corporations, and organizations to solve the incredible challenges ahead. GCE is uniquely positioned to contribute to societal needs, and ICTs are tools that can be bent to the task.

In the end, either with human beings or machines, the creation of "communities of difference" (Tierney \& Rhodes, 1993) that allow for diverse human perspectives as well as discourse will continue with the utilization of ICTs. This community of difference ideal allows for the hope for "team intelligence" among humans and machines with different cultural, educational, and civic backgrounds. This collaborative intelligence is, I believe, our hope going forward for GCE and education at large. In recent GCE scholarship, some ideas have been posited for the utilization of ICTs to achieve GCE goals: harnessing technology to reframe GCE as a transnational social movement (Torres, 2017a), fostering global citizenship through online research (Harshman \& Augustine, 2013), videogames (Marino \& Hayes, 2012), and creating personal digital narratives (Truong-White \& McLean, 2015) to upend traditional learning styles and incorporate dialogues present in GCE curricula.

ICTs are powerful tools. Whether wielded by an authoritarian regime to target a minority population or by Cambridge Analytica to farm human behavior to impact a national election far beyond what has happened in the past, or utilizing data and ICTs to share climate change studies, human rights needs, or disaster relief, these technologies have fundamentally altered human existence and interaction. Moving forward in reassessing the role that ICTs can have on GCE, scholars and participants can adapt the tenets of GCE to the infosphere. GCE voices and perspectives can be amplified, but it must be done in a structured and systematic way that can counter and refute nationalism and political divisiveness. Up to this point, division based on the tribal impulses of humanity has eclipsed cooperation and compassion. Using the organizations and initiatives such as the Sustainable Development Goals of the UN, as well as viral movements based in democratic ideals and freedom of expression, and Greta Thunberg's protest and legal challenge to raise awareness of climate change inaction, GCE values can be amplified through ICTs to form communities of difference with value-laden agendas that counter hegemonic power structures and cut through the far removed hyperreality of corporate and government messaging. 
Swarts, G.P Re/coding Global Citizenship: How Information and Communication Technologies have Altered Humanity and Created New Questions for Global Citizenship Education

\section{References}

Al Now Report. (2017). Al Now Institute. Retrieved from https://ainowinstitute.org/

Amnesty International. (2018, February 27). When profits threaten privacy: 5 things you need to know about Apple in China. Retrieved from https://www.amnesty.org/en/latest/news/2018/02/5-things-you-need-to-knowabout-apple-in-china/

Andreotti, V. D. O., \& Pashby, K. (2013). Digital democracy and global citizenship education: Mutually compatible or mutually complicit? The Educational Forum, 77(4), 422-437.

Baker, R. S. (2016). Stupid tutoring systems, intelligent humans. International Journal of Artificial Intelligence in Education, 26(2), 600-614.

Baudrillard, J. (1994/2004). Simulacra and simulation. Ann Arbor, MI: University of Michigan Press.

Baudrillard, J. (2007). The intelligence of evil: Or, the lucidity pact. Oxford, UK: Berg Publishing.

Botsman, R. (2017, November 28). Big data meets Big Brother as China moves to rate its citizens. Wired. Retrieved from http://www.wired.co.uk/article/chinesegovernment-social-credit-score-privacy-invasion

Cammaerts, B. (2017). ICT-usage among transnational social movements in the networked society: To organise, to mobilise and to debate. In R. Silverstone (Ed.), Media, technology and everyday life in Europe (pp. 71-90). London, UK: Routledge.

Christensen, B. (2019). Cyber state capacity: A model of authoritarian durability, ICTs, and emerging media. Government Information Quarterly, 36(3), 460-468.

Christensen, B., \& Groshek, J. (2019). Emerging media, political protests, and government repression in autocracies and democracies from 1995 to 2012. International Communication Gazette, 1-20.

Combi, C. (2015). Generation Z: Their voices, their lives. New York, NY: Random House

Dellinger, A. J. (2019, August 22). Standardized tests are historically racist and classistAdding Al will just make it worse. Mic. Retrieved from 
Swarts, G.P Re/coding Global Citizenship: How Information and Communication Technologies have Altered Humanity and Created New Questions for Global Citizenship Education

https://www.mic.com/p/standardized-test-algorithms-used-for-grading-arereinforcing-human-biases-18683017

Dewey, J. (1907). School and society. Chicago, IL: University of Chicago Press.

Draper, R. (2018, February). They are watching you-And everything else on the planet. National Geographic Magazine. Retrieved from https://www.nationalgeographic.com/magazine/2018/02/surveillancewatching-you/

Edwards, R., \& Usher, R. (2002). Postmodernism and education: Different voices, different worlds. New York: NY. Routledge.

Floridi, L. (2010). Information: A very short introduction. Oxford, UK: Oxford University Press.

Floridi, L. (2011a). The informational nature of personal identity. Minds and Machines, 21(4), 549-566.

Floridi, L. (2011b). The construction of personal identities online. Minds and Machines, 21(4), 477-479.

Floridi, L. (2014). The fourth revolution: How the infosphere is reshaping human reality. Oxford, UK: Oxford University Press.

Hanvey, R. (1976). An attainable global perspective. The American Forum for Global Education. Center for War/Peace Studies. New York, NY.

Hao, K. (2019, August 3). China has started a grand experiment in Al education. It could reshape how the world learns. MIT Technology Review. Retrieved from https://www.technologyreview.com/s/614057/china-squirrel-has-started-agrand-experiment-in-ai-education-it-could-reshape-how-the/

Harshman, J. R., \& Augustine, T. A. (2013). Fostering global citizenship education for teachers through online research. The Educational Forum, 77(4), 450-463.

Hart, D., Richardson, C., \& Wilkenfeld, B. (2012). Civic identity. In Handbook of identity theory and research, vol. 2 (pp. 771-787). New York, NY: Springfield.

Harwell, D. (2019, August 28). Doorbell-camera firm Ring has partnered with 400 police forces, extending surveillance concerns. The Washington Post. Retrieved from https://www.washingtonpost.com/technology/2019/08/28/doorbell-camerafirm-ring-has-partnered-with-police-forces-extending-surveillance-reach/ 
Swarts, G.P Re/coding Global Citizenship: How Information and Communication Technologies have Altered Humanity and Created New Questions for Global Citizenship Education

Haskins, C. (2019, August 28). Ring says it's partnered with 405 police departments, here's what we still don't know. VICE News. Retrieved from https://www.vice.com/en us/article/a35vy4/ring-says-its-partnered-with-405police-departments-heres-what-we-still-dont-know

Helbing, D., Frey, B. S., Gigerenzer, G., Hafen, E., Hagner, M., Hofstetter, Y., van den Hoven, J., Zicari, R., \& Zwitter, A. (2019). Will democracy survive big data and artificial intelligence? Scientific American. Retrieved from https://www.scientificamerican.com/article/will-democracy-survive-big-dataand-artificial-intelligence/

Hongladarom, S. (2011). Personal identity and the self in the online and offline world. Minds and Machines, 21(4), 533.

Howard, J. (2016, July 29). Americans at more than 10 hours a day on screens. CNN. Retrieved from https://www.cnn.com/2016/06/30/health/americans-screentime-nielsen/index.html

International Society for Technology in Education (ISTE). (2019). ISTE standards for students, \#2: Digital citizen. Retrieved from https://www.iste.org/standards/forstudents

Kayali, L. (2018, January 28). Special report: Confusion reigns in wake of safe harbor ruling. Politico. Retrieved from https://www.politico.eu/article/special-reportconfusion-reigns-in-wake-of-safe-harbor-ruling/

Luckin, R., Holmes, W., Griffiths, M., \& Forcier, L. B. (2016). Intelligence unleashed: An argument for $\mathrm{Al}$ in education. London, UK: Pearson.

Malcomson, S. (2016). Splinternet: How geopolitics and commerce are fragmenting the world wide web. New York, NY: OR Books.

Marino, M. T., \& Hayes, M. T. (2012). Promoting inclusive education, civic scientific literacy, and global citizenship with videogames. Cultural Studies of Science Education, 7(4), 945-954.

Mikander, P. (2016). Globalization as continuing colonialism: Critical global citizenship education in an unequal world. Journal of Social Science Education, 70-79.

Moss, D. M. (2018). The ties that bind: Internet communication technologies, networked authoritarianism, and 'voice' in the Syrian diaspora. Globalizations, 15(2), 265-282. 
Swarts, G.P Re/coding Global Citizenship: How Information and Communication Technologies have Altered Humanity and Created New Questions for Global Citizenship Education

National Association for the Advancement of Colored People (NAACP). (2019). LogOut Facebook. NAACP. Retrieved from https://www.naacp.org/logout-facebook/

Neff, D. (2015). Digital exhaust: What everyone should know about big data, digitization, and digitally driven innovation? New York, NY: FT Press

Organization for Economic Cooperation and Development (OECD). (2018). Report: Preparing our youth for an inclusive and sustainable world. Retrieved from https://www.oecd.org/education/Global-competency-for-an-inclusive-world.pdf

Oxfam Education. (2019). What is Global Citizenship? Retrieved from https://www.oxfam.org.uk/education/who-we-are/what-is-global-citizenship

Pais, A., \& Costa, M. (2017). An ideology critique of global citizenship education. Critical Studies in Education, 1-16.

Robbins, S., \& Henschke, A. (2017). The value of transparency: Bulk data and authoritarianism. Surveillance \& Society, 15(3/4), 582-589.

Romm, T. (2019, February 18). Facebook "intentionally and knowingly" violated U.K. privacy and competition rules, British lawmakers say. The Washington Post. Retrieved from https://www.washingtonpost.com/technology/2019/02/18/facebookintentionally-knowingly-violated-uk-privacy-competition-rules-britishlawmakers-say/?noredirect=on

Roscorla, T. (2012, September 20). Should students be tracked with radio frequency ID tags? Center for Digital Education. Retrieved from https://www.govtech.com/education/Should-Students-be-Tracked-with-RadioFrequency-ID-Tags-GT.htm|

Satariano, A. (2019, May 6). Europe is reining in tech giants. But some say it's going too far. New York Times. Retrieved from https://www.nytimes.com/2019/05/06/technology/europe-techcensorship.html

Scott, M., \& Gold, A. (2018, February 26). Supreme Court to hear arguments in global digital privacy case. Politico. Retrieved from https://www.politico.com/story/2018/02/26/supreme-court-digital-privacycase-359711 
Swarts, G.P Re/coding Global Citizenship: How Information and Communication Technologies have Altered Humanity and Created New Questions for Global Citizenship Education

Statista. (2019). Global regional internet penetration rates, 2019. Retrieved from https://www.statista.com/statistics/269329/penetration-rate-of-the-internetby-region/

Swarts, G. P. (2019). The school of "onlife": How technology and educational data will force us to rethink teaching and learning. Teachers College Record, commentary. Retrieved from http://www.tcrecord.org/content.asp?contentid=22648

Tierney, W. G., \& Rhoads, R. A. (1993). Postmodernism and critical theory in higher education: Implications for research and practice. Higher Education: Handbook of Theory and Research, 9, 308-343.

Torres, C. A. (2017a). Global Citizenship Education: A New Global Social Movement? In Theoretical and empirical foundations of critical global citizenship education (pp. 104-140). New York, NY: Routledge.

Torres, C. A. (2017b). Theoretical and empirical foundations of critical global citizenship education (Vol. 1). New York, NY: Routledge.

Truong-White, H., \& McLean, L. (2015). Digital storytelling for transformative global citizenship education. Canadian Journal of Education, 38(2), 1-28.

UNESCO. (2019). What is global citizenship education? Education 2030 Agenda and Framework for Action. Retrieved from https://en.unesco.org/themes/gced/definition

van Kessel, C., \& Kline, K. (2019). "If you can't tell, does it matter?" Westworld, the murder of the real, and 21st century schooling. Journal of Curriculum and Pedagogy, 1-21.

Webb, A. (2019). The big nine: How the tech titans and their thinking machines could warp humanity. New York, NY: Public Affairs. 